Article

\title{
Vision-Based Decision-Making Methodology for Riparian Forest Restoration and Flood Protection Using Nature-Based Solutions
}

\author{
Maria A. Lilli ${ }^{1, *}$, Sofia D. Nerantzaki ${ }^{1}$, Christos Riziotis ${ }^{1}$, Manolis Kotronakis ${ }^{1}$, \\ Dionissis Efstathiou ${ }^{1}$, Dimitris Kontakos ${ }^{2,3}$, Petros Lymberakis ${ }^{2}$, Manolis Avramakis ${ }^{2}$, \\ Antonis Tsakirakis ${ }^{2}$, Konstantinos Protopapadakis ${ }^{1}$ and Nikolaos P. Nikolaidis ${ }^{1}$ \\ 1 Department of Environmental Engineering, Technical University of Crete, 73100 Chania, Greece; \\ snerantzaki@isc.tuc.gr (S.D.N.); riziotisc@gmail.com (C.R.); kotronakis@gmail.com (M.K.); \\ dionissis.efstathiou@enveng.tuc.gr (D.E.); kprotop@gmail.com (K.P.); \\ nikolaos.nikolaidis@enveng.tuc.gr (N.P.N.) \\ 2 Natural History Museum of Crete, School of Science and Engineering, University of Crete, 71409 Heraklion, \\ Greece; kontakosd@samaria.gr (D.K.); lyberis@nhmc.uoc.gr (P.L.); avram@nhmc.uoc.gr (M.A.); \\ ant.tsaki@gmail.com (A.T.) \\ 3 Management Body of Samaria National Park-Western Crete, Old National Road Chania-Kissamos, \\ Kato Daratso, 73100 Chania, Greece \\ * Correspondence: marialilli02@gmail.com; Tel.: +30-2821037784
}

Received: 26 March 2020; Accepted: 16 April 2020; Published: 18 April 2020

check for updates

\begin{abstract}
Nature-based solutions (NBS) are actions that use natural processes in a resource efficient manner to solve societal challenges. The lack of supportive legislature, and financial, communication and social barriers complicate the process of NBS implementation. It is an urgent need to develop approaches to design and implement NBS that would act as drivers to overcome potential barriers and enhance the social acceptability of the project. The vision-based decision-making methodology and participatory process created in this study has been carried out in the Koiliaris Critical Zone Observatory in Crete to design erosion and flood protection NBS and restore the riparian forest. The methodology consists of four distinct steps as follows: i) develop a vision of the area, ii) conduct a baseline assessment study, iii) NBS design and co-design, and iv) procurement and implementation. The methodology overcame multiple barriers because of the effective stakeholder engagement and the vision "drove" the project and created the necessary consensus that is necessary to achieve the objective of converting privately owned prime agricultural land to riparian forest. It offers an exemplar of a functional ecosystem restoration project that protects the river in a sustainable way, improves its biodiversity and water quality and improves the quality of life and social cohesion.
\end{abstract}

Keywords: nature-based solutions; climate change; ecological restoration; flood risk management; stakeholder involvement; decision-making

\section{Introduction}

Nature-based solutions (NBS) are defined as actions inspired by, supported by, or copied from nature [1], that deploy various natural features and processes, are resource efficient and adapted to systems in diverse spatial areas. NBS address global challenges such as social, environmental and economic issues, and lead to multiple benefits that enhance the resilience of ecosystems [2]. The European Union (EU) has adapted NBS as a strategy for achieving sustainable urbanisation, the restoration of degraded ecosystems, climate change adaptation and mitigation, and the improvement of the risk management of, and resilience to, extreme events [3]. 
In recent years, NBS has been widely adopted as a term and pushed forward in the EU Research and Innovation Policy agenda, in order to promote synergies between nature, society, and the economy [4]. The Research and Innovation roadmap of the European Commission has been promoting NBS at the European and international level in order to establish the EU as a world leader on NBS. To achieve this, the EU is aiming to establish the NBS evidence and knowledge base, develop a repository of best practices, create a NBS community of innovators, and promote and market the EU research and innovation NBS agenda globally [5].

Disasters triggered by natural hazards, and specifically those related to climate change and climate variability, such as flood and drought, are becoming more extreme over time. They have been among the main concerns of the European emergency management authorities [6], leading policymakers toward the implementation of innovative risk management strategies and solutions [7]. The positive outcomes of NBS on risk management and climate change adaptation and mitigation are constantly growing [8], provided that behind their implementation there is a strategic plan and interconnection in a network of solutions [9]. Moreover, sustainable stakeholder-proposed management policies should be applied with a holistic understanding of the complex social-economic-environmental context [10].

However, NBS face many implementation barriers, such as technical, policy or legislative, market, and communication barriers. Inadequate technical knowledge regarding the design and implementation of NBS has been identified as an obstacle for effective implementation [11]. The knowledge gaps refer to the design, implementation and maintenance of NBS, the quantification of the benefits and co-benefits, and the monitoring and assessment of the effectiveness of NBS [9,12]. Rizvi et al. [13] indicated that there is a lack of a conclusive evidence base to highlight the effectiveness of ecosystems-based approaches to deal with climate change. Wamsler et al. [14] identified five strategies which can be applied in order to overcome the multiple constraints that face NBS. These are: i) targeted stakeholder collaboration; ii) strategic citizen involvement; iii) the dissemination of information and advisory services for NBS implementation; iv) the integration of work among different departments; v) streamlining NBS science into planning regulations. Moreover, the success of strong bottom-up collaborative partnerships leads to the successful implementation of NBS and the replication of initiatives [15].

Climate change adaptation and mitigation is a key element in terms of resilience, developed through an operational framework that allows local planners to define approaches and practical strategies for implementation [16]. Understanding the dynamics of whole the system [17], as well as the development of frameworks that recognize the multiple benefits and co-benefits of NBS for society, constitutes a valuable tool for decision-making processes [18]. Traditional alternatives to river bank erosion and flood protection involve grey infrastructures that do not maintain the ecology of the river, enlarge the river bed and in general do not contribute to the resilience of the system to climate change. The design of grey infrastructures has been mainstreamed both in terms of technical design as well as of governmental permitting and, therefore, do not have socio-economic and political barriers that would forestall their implementation. On the other hand, land use management using blue-green, nature-based technologies requires co-design with the involvement of stakeholders, participatory planning and social consensus, as well as overcoming governmental permitting that has not been mainstreamed.

NBS alternatives in many countries are not even being considered due to a lack of existing policies to support the development of NBS over traditional infrastructure development. Even in cases where they are being considered, the lack of supportive legislature becomes a major barrier for its implementation. On top of that, major communication and social barriers arise due to the lack of common language and the multidisciplinary role of stakeholders with different experience and areas of expertise. Within this context, the objective of this research is to develop a vision-based decision-making approach to designing and implementing NBS that would act as a driver to overcome potential barriers and enhance the social acceptability of the project. In particular, we intend to illustrate this approach using the riparian forest restoration and flood protection project conducted at the Koiliaris Critical Zone Observatory in Crete. 


\section{Materials and Methods}

\subsection{Site Description}

The Koiliaris River watershed is a Critical Zone Observatory (CZO) (www.koiliaris-czo.tuc.gr) that represents severely degraded soils due to heavy agricultural impacts, including grazing, over many centuries. It represents Mediterranean soils under imminent threat of desertification (i.e., soil carbon loss) due to climate change that is predicted by the UN IPCC for the region over the next century. It is located in Western Crete, Greece. There are 17 communities in the catchment. The total area is $130 \mathrm{~km}^{2}$ and the total length of the river is $36 \mathrm{~km}$. The Koiliaris River basin (KRB) extends from sea level to an elevation of $2100 \mathrm{~m}$ above sea level. Most of the watershed has steep slopes up to $45 \%$ that level out at valley and become mild (1-2\%). The valley is prone to flooding of the riparian forest and agricultural area. Flash flooding is caused by high precipitation events that exceed the infiltration rate of the karst [19] and generate significant quantities of surface runoff.

Intensive hydrologic and geochemical monitoring has been conducted since 2004, while the site has historical data from the 1960s onwards. In addition, high-frequency hydrologic and water quality monitoring stations have been deployed to obtain data for the characterization of the hydrologic and biogeochemical processes with varying process response-times. There are 3 meteorological stations within the watershed and several outside. Water quality data of surface and groundwater have been collected since 2004 .

Koiliaris CZO is an exemplary site for studying the Mediterranean soils under imminent threat of desertification due to climate change. The main type of soil degradation in the basin is water erosion, which is due to the clearing of forests and natural vegetation for cropping and livestock grazing. De-vegetation and inappropriate cultivation practices induces soil organic matter losses making soils susceptible to erosion and desertification with global consequences for food security, climate change, biodiversity, water quality, and agricultural economy. The riparian forest of Koiliaris has been established along the $11 \mathrm{~km}$ of river length. Agricultural expansion has resulted in cutting down the trees and cultivating the area with olive trees, citrus and avocado plantations and other crops. From aerial photographs we know that this expansion occurred before 1945. Today only the last row of the trees along the river mostly remain and are prone to bank erosion. In many cases, the river has eroded the bank and makes the tree susceptible to failure. The areal extent of the riparian forest before the agricultural expansion was close to the flooded area of the Koilaris River. Today, we observe the remaining remnants of the forest (individual trees) 30-50 m away from the river.

\subsection{Methodological Approach}

The vision-based decision-making methodology and participatory process had been carried out in Koiliaris case study in order to design erosion and flood protection NBS and restore the riparian forest. There were several distinct steps from the conceptualization of a flood protection problem to the implementation and performance evaluation. The whole methodological process adopted in this study was comprised of four phases and is presented in Figure 1. 


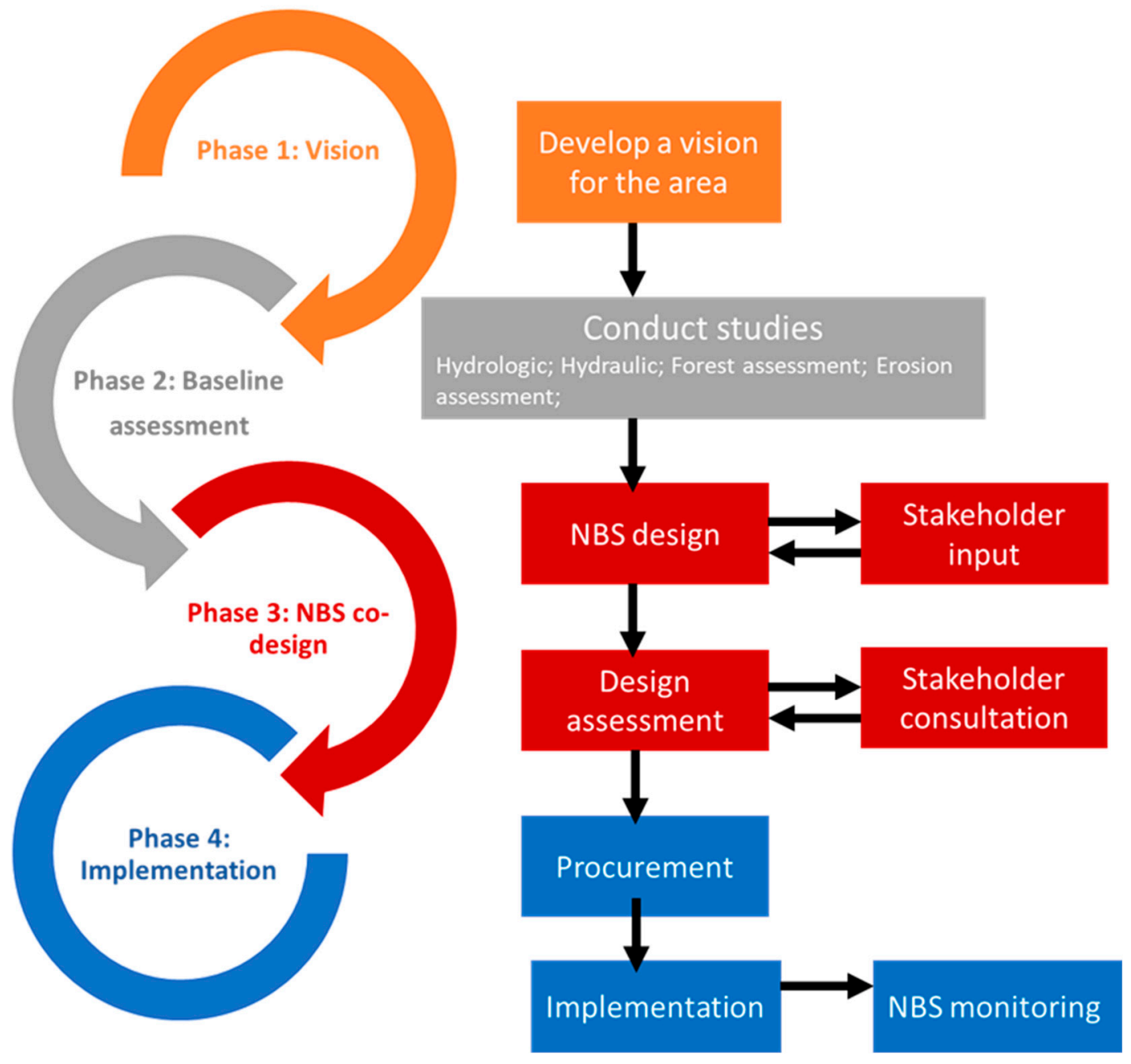

Figure 1. Decision-making methodology scheme for NBS implementation.

The first phase of the methodology was the development of a vision for the area. This vision drove the project and the local stakeholders to achieve consensus and overcome the many barriers that arose from the implementation. To develop such a vision, it was important to identify the environmental and ecological problems of the area in order to define a holistic approach for solving them that would give added value to the region and enhance its resilience. This vision brought local stakeholders and the decision-makers on board in order to materialize the project.

Once the vision was established, it was important to find the funding and to conduct the baseline studies that were necessary for the environmental assessment and obtain the data for the design of alternative solutions. For instance, in our case, a flood protection study involved the following baseline studies:

- Delineation of the floodplain of the river for the 50-year flood which involved the following actions:

- Detailed surveying of the river and the surrounding area

- Hydrologic study for the identification of the 50-year flood

- Hydraulic study to delineate the floodplain

- Analysis of the susceptibility to flood erosion (bank erosion)

- Forest assessment

The next phase dealt with the NBS design and co-design. This stage involved the design of alternatives of NBS measures for flood protection and for the restoration of riparian forest, as well 
as an environmental impact assessment study that assessed the comparison of the different design alternatives. During this phase, participatory activities allowed effective stakeholder involvement in the co-design of the final NBS. Stakeholder meetings were carried out to co-design and overcome potential barriers of conflicting interests. The stakeholders involved in the processes should be representatives in different roles who are related to at least one of the attributes of power, legitimacy, urgency, or interest [20].

Once the design had been finalized, it should be submitted to the Regional Government to receive the necessary approvals and permits. After that, the local government had to secure funding for implementation (local resources, structural funds, other sources), and proceed with its procurement and implementation. The last step of the methodology included the monitoring of the effectiveness of the NBS. Key indicators should be established to monitor the effectiveness of NBS and take corrective actions.

\section{Results and Discussion}

\subsection{Vision Phase}

Koiliaris CZO (a member of the LTER Europe Network) was established as an observatory by the Technical University of Crete in 2004. Since then, many graduate students and post docs from the Technical University of Crete and other institutions from Europe, the USA, and China have been conducting research on water and soil management. Results have been published in over 40 peer-reviewed journal publications [21]. Funding from several European and Greek funding agencies (EU Projects: SoilTrec, SoilCritZone, eLTER, adv_eLTER, eLTER-PLUS, eLTER-PPP; Greek Projects: CyberManagement, Thallis-Cybersensors, EEA Aquaman and the present project funded by the Region of Crete) have provided the resources to a) establish the necessary monitoring stations and equipment to collect long-term data, b) develop a comprehensive understanding of the hydrologic and geochemical functioning of the watershed, and c) develop tools and methodologies for the sustainable management of water and soil resources that would lead to sustainable agricultural development for the area.

For 15 years the presence of the Technical University of Crete in the area has been continuous. We have been in constant contact with the local stakeholders, from the Mayor of the Municipality of Apokoronas to the local farmers and to Regional Officials. In addition, the economic crisis in Greece of the past 10 years and the three austerity programs created the underlying conditions to initiate a grassroots discussion for agricultural development. We have made many presentations in gathering with farmers discussing issues of agricultural development, soil sustainability and water management. The Technical University of Crete has become a well-accepted local "Institution" that guides public opinion on the issues of water resources and climate change adaptation and mitigation.

With this as a background, these local town hall meetings have shaped the vision for sustainable agricultural development that is closely linked with the karstic springs of White Mountains and Koiliaris River. The ecological quality of Koiliaris River based on the aquatic monitoring by the Ministry of the Environment is high. In addition, the riparian forest and the river is tightly connected with the agricultural, touristic and recreational activities of the area.

However, agricultural expansion to the river has resulted in cutting down the trees of the riparian forest and cultivating the area with olive trees, citrus and avocado plantations, minimizing the extent of the riparian forest and its benefits. For this reason, during the past 20 years, significant bank erosion is taking place of the lower tributaries and the main course of Koiliaris River and the riparian forest has been reduced to a single line of trees by the river bank.

The significance of the problem in the Koiliaris River was identified after the spring of 2004 flood that caused major bank erosion, resulting in the over-topping of the riparian trees and the overall degradation of the river ecosystem in the area. The Municipality at that time partially restored the areas eroded in order to protect the remaining trees, but since then, no erosion protection works occurred. 
We have raised the issue of the degradation of the riparian forest and the urgent need for restoration since the early years of the establishment of the observatory. Restoration of the riparian forest entailed, in this case, converting agricultural land (private property) to forest, and the socio-economic situation was not favorable toward initiating such a project.

There are multiple drivers that affect governmental decisions to tackle the issue of flood protection in Greece at various levels, the most important of which is public pressure and intense media scrutiny after an extreme event. It is well accepted in Greece that climate change and extreme events increase the number and magnitude of natural disasters. Such extreme events, in addition to property loss, often have human fatalities and become the primary cause for grass root movements that accelerate decision making and bypass bureaucratic procedures and governmental inactivity. Recent examples in Greece are the extreme floods in 2017 and the fires in 2018 in Attica, where many people died and property was destroyed. These events reinforce the need for protection from natural disasters. Greece, until recently, delayed the implementation of the flood management plans that are designed to develop the overall strategy for mitigating the impacts of extreme events as well as identifying the areas vulnerable to flooding; therefore, major, much-needed flood protection projects were not under consideration.

The unfortunate cases of 2017 and 2018 mobilized the regional government and the municipalities in seeking funding for flood protection projects and initiating appropriate studies. Finally, an extreme flood occurring in October 2017 in the KRB, with more than 2.2 million cubic meters of water being transported in $12 \mathrm{~h}$, caused additional damage in the area and deteriorated the riparian forest, necessitating the study of its restoration. The conditions matured for the funding of the project. Locals and regional decision-makers were persuaded and agreed with the importance of the problem and, since then, they have had to identify the funding mechanism, write the specifications of the study, and follow the procurement mechanism.

The vision of the project was to develop bank erosion protection and flood protection using NBS and restore the extent of the riparian forest to $20 \mathrm{~m}$ on both sides of the river, creating a 5-km riparian forest corridor that will become the trade mark for the agricultural development of the area. The farmers giving up prime agricultural land to re-establish the extent of the riparian forest will send a message that "we care for sustainable land management" and that "we care to produce quality agricultural products". This vision has kept the idea of the riparian forest restoration alive for the past 15 years until the right conditions materialized for its implementation.

\subsection{Baseline Assessment Phase}

\subsubsection{Hydrologic Study}

The KRB is a watershed with karstic formations. Like many Mediterranean watersheds, the hydrologic pathways of KRB is complex, consisting of a combination of surface runoff and karstic flow, originating from a system of karstic springs. The modelling of such watersheds demands the use of developed, operational models which can capture the variability of the complex flow. A variety of models have been introduced during the past 10 years to accomplish this task $[19,22,23]$. In the context of this study, the Karst-SWAT model [23] is used to model the flow of the surface and karstic springs of $\mathrm{KRB}$, using observed flow data from hydrological stations.

More specifically, surface runoff in the watershed is formed by two main intermittent streams: Keramianos and Anavreti. Data for the simulation of surface flow are provided by a hydrometric station, situated along the Keramianos tributary. The classic SWAT approach is used for the determination of the surface runoff using the station located at Keramianos. Another hydrometric station, situated at the basin exit, supplies high frequency flow data which constitute a combination of surface and karstic flow. This station is used for the calibration of total flow at the basin exit, simulated using the Karst-SWAT model. All springs are modeled as one, based on the karstic two-reservoir model, developed by Nikolaidis et al. [23], which is incorporated in the Karst-SWAT model. 
However, two types of karstic springs can be identified in the KRB: the Stylos springs and the Anavreti spring. The Anavreti spring has $8 \mathrm{~m}$ higher elevation than the Stylos springs. Therefore, although defined by the same karstic system, they present different responses. The Stylos springs have permanent flow during the year, whereas the spring of Anavreti runs only when the springs flow exceeds $4 \mathrm{~m}^{3} / \mathrm{s}$; this occurs during specific months, usually between December and March. We used historical data of the Stylos and Avavreti flows to develop the relationship that would apportion the total flow of the karst simulated by the model to the individual flows of the two springs.

The hydrologic study has the advantage of providing flow simulations for every point in the watershed as well as for both Stylos and Anavreti springs. These values can further be used for the determination of the design flow and the subsequent flood frequency and hydraulic analysis for each point of interest.

\subsubsection{Hydraulic Study}

The objective of the hydraulic study was to identify the 50-year return flood $\left(\mathrm{Q}_{50}\right)$ for every stream segment and for each of the springs. A detailed assessment of flood frequency was conducted, separating the surface from the groundwater flow, as well as the individual surface flows of each stream and karstic flows of each spring. An analysis of extreme hydrological events was performed based on the annual maximum flow values of the 58-year simulated time series (1961-2018). The daily flows from 1961 to 2018 were processed using the statistical techniques of Gumbel and Log Pearson Type 3. The maximum annual flow for each cross section of the river was selected, based on the statistical analysis of the two methods.

The results showed that the Gumbel method presented smaller correlation errors and a greater regression coefficient, ranging from 0.85 to 0.98 . The design flow was calculated $10.5 \mathrm{~m}^{3} / \mathrm{s}, 32.4 \mathrm{~m}^{3} / \mathrm{s}$, $43.7 \mathrm{~m}^{3} / \mathrm{s}, 16.1 \mathrm{~m}^{3} / \mathrm{s}$, and $55.5 \mathrm{~m}^{3} / \mathrm{s}$ for the Stylos spring, Anavreti tributary, Mantamas, Keramianos and Agios Georgios station, respectively.

For the hydraulic simulation of the system, it is important to convert the daily design flows with a 50-year return period determined from the statistical evaluation of the simulated data to hourly design flow. To do that, observed flood flow data from the hydrometric station at the basin exit (Agios Georgios) were used, in conjunction with the daily design flow estimated by the SWAT model. The 12 most significant flood episodes observed during the period 2007-2019 were examined and normalized flood frequency distribution curves were developed for each flood. Two of the floods had a duration of $24 \mathrm{~h}$ and the remaining ten a duration of $12 \mathrm{~h}$. The most adverse flood, i.e., the flood which has the largest ratio of maximum hourly to total flow, was the one that took place on October 27th, 2017 and its frequency distribution was selected to convert the daily design flow to hourly. The daily estimated design flow $\left(Q_{50}\right)$ derived from the SWAT model for the main stream of Koiliaris $\left(55.5 \mathrm{~m}^{3} / \mathrm{s}\right.$ at the basin exit) was converted to hourly flow, using the hourly normalized distribution of the latter flood event. The maximum hourly flow was $19.0 \%$ of the total daily volume of water of the flood and this corresponds to an hourly design flow of $127.5 \mathrm{~m}^{3} / \mathrm{s}$. Therefore, a safety factor of 2.3 was included in the design. Using the same safety factor, the design hourly flows for the Anavreti, Keramianos, Stylos, and Madamas were estimated to be $74.5 \mathrm{~m}^{3} / \mathrm{s}, 37.0 \mathrm{~m}^{3} / \mathrm{s}, 24.2 \mathrm{~m}^{3} / \mathrm{s}$, and $100.5 \mathrm{~m}^{3} / \mathrm{s}$, respectively.

Having the design flows, the HEC-RAS model [24] was used to determine the floodplain of Koiliaris River for the 50-year return flood. The model is one-dimensional and covers all types of flow for open streams. The data of the detailed surveying of the river and the surrounding area, were used for the determination of the critical water surface elevation. The flood routing was determined for all tributaries of Koiliaris. The floodplain was defined as the dashed lines connecting the intersection points of the water surface in a series of cross sections with the natural or landscaped terrain in the same cross sections (Figure 2).

The flow in the beds is assumed to be non-uniform, due to the constant change in the shape of the cross-section and the bottom slope. Hydraulic calculation of permanent non-uniform flow is achieved by using the Energy Equation and a Manning value equal to 0.05 (natural stream). The input 
data include the geometrical data of each bed and the peak flood flow, as calculated above for each stream branch. A uniform flow depth upstream and downstream of each bed section was obtained as a boundary condition. Floodplains with flood lines were constructed for all streams. As it is obvious from Figure 2, the width of the flood is higher downstream of the Stylos (average width of $65.0 \mathrm{~m}$ ) and Anavreti $(30.6 \mathrm{~m})$ springs, and continues to be significant throughout the Koiliaris main stream $(75.2 \mathrm{~m}$ with a maximum of $127 \mathrm{~m}$ ). The Keramianos tributary and the Anavreti stream, on the other hand, present lower flood widths (25.5 and $30.6 \mathrm{~m}$, respectively). Anavreti has a higher contribution to the flood of the main stream of Koiliaris compared to Keramianos.

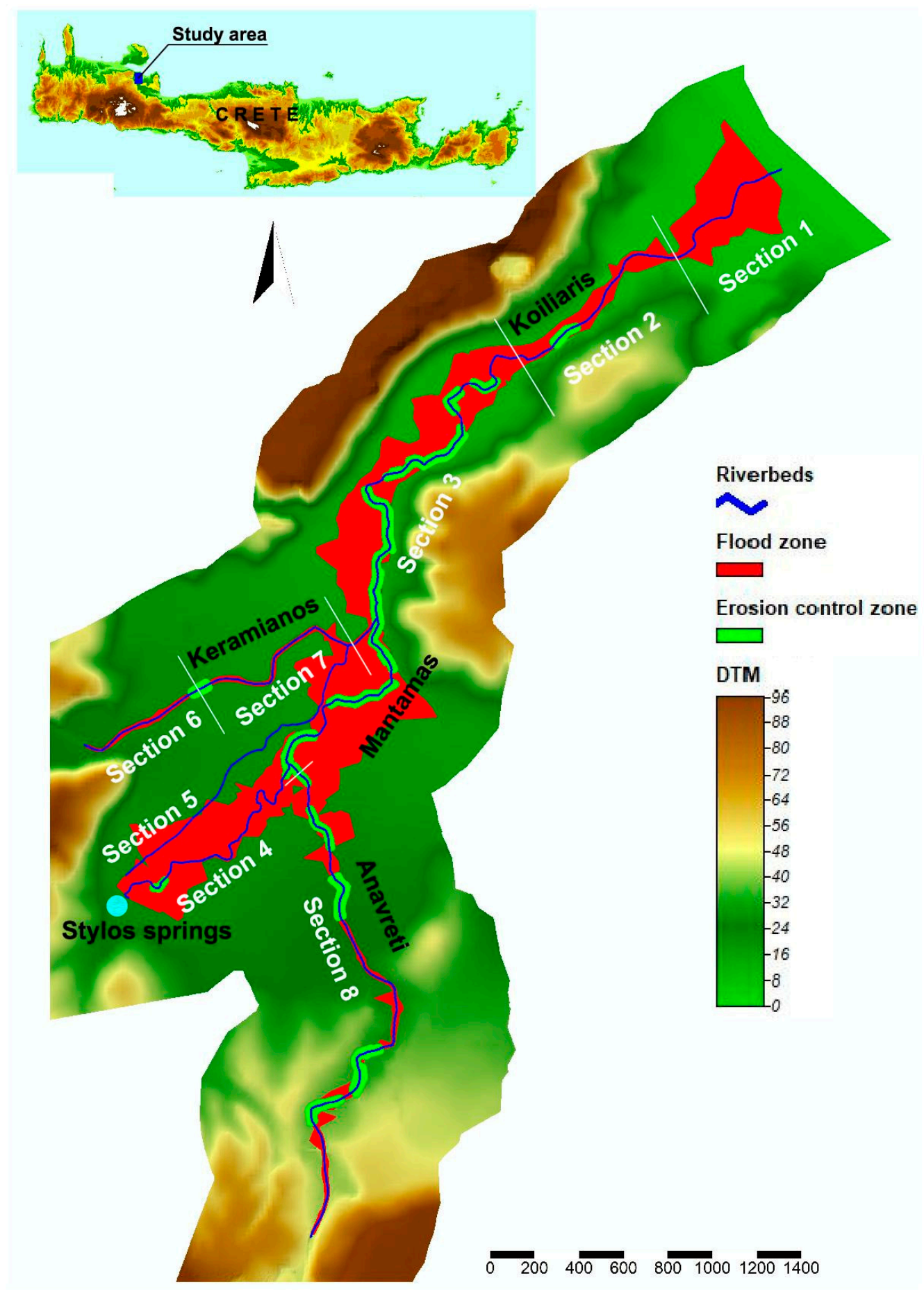

Figure 2. The flood and erosion control zones in the Koiliaris River. 


\subsubsection{Erosion Assessment Study}

The objective of the erosion study was to conduct an analysis of bank erosion and bank failure assessment. It was conducted after the floods of February 2019. The assessment consisted of a three-prong approach: 1) Field surveys for the identification of the cross sections of the bank and riverbed that have been eroded or are prone to erosion. 2) Soil samples collection for the characterization of the soil composition of the banks. 3) Bank erosion and failure risk estimation using the Bank Stability and Toe Erosion Model (BSTEM). BSTEM is integrated in version 5.0.6 of the HEC-RAS model.

Figure 1 presents the cross sections that have been identified from the field survey that have been eroded or that are prone to erosion. Out of a total 268 sections of the river, 80 were determined as those needing restoration and protection measures in one or both banks. These are cross sections located mostly in river bends and have degraded vegetation. By degraded vegetation we mean that the existing vegetation does not have the rooting system to keep the soil from erosion. An example is a field where the orange trees had replaced the indigenous vegetation of plane and willows trees.

The characterization of soil samples was conducted based on particle size distribution and the limits of A.S.T.M. The soil samples analyzed by means of sieves had a mass-median-diameter (D50) ranging between $0.07 \mathrm{~mm}$ and $0.75 \mathrm{~mm}$ and were characterized as "very fine sand" to "coarse sand". The diameters D10, D30 and D60 for these samples were calculated $0.052 \pm 0.022,0.136 \pm 0.097$, and $0.396 \pm 0.279 \mathrm{~mm}$, respectively. The uniformity coefficient $(\mathrm{Cu})$ ranged between 1.83 and 18.41, indicating that the majority of the samples were well graded. The coefficient of curvature (Cc) was calculated between 0.03 and 1.86. Analyses of the samples collected from the Koiliaris River showed that the composition of the riverbanks was sandy soils. The characterization of soil texture was a necessary input for the BSTEM model.

The simulation of bank erosion and the determination of the factor of safety (Fs) was conducted for the 80 cross sections (both for the right and left banks or 160 banks) that were prone to erosion (identified from the field survey).

The results showed that the Fs for 55 of the total 160 river sections studied, was between $0-0.99$, suggesting unstable banks. The Fs for 77 banks calculated between 1-1.3, suggesting conditionally stable banks, i.e., stable but with little safety margin. The Fs for 28 banks was greater than 1.3 suggesting stable banks (Figure 3). For each of the 132 banks found to be unstable or conditionally stable, measures for flood protection and for the restoration of riparian forest were proposed, as will be discussed later in this manuscript. These measures were vegetated stone walls and vegetated rip-raps. The proposed restored cross sections were simulated with the model to ensure that the measures will be effective and the banks stable.

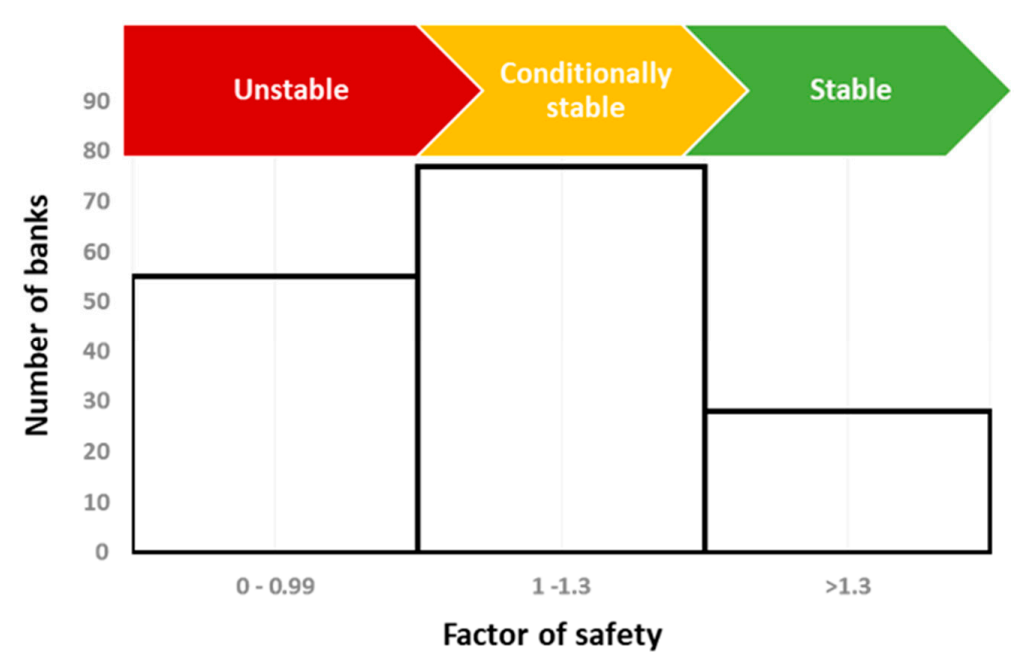

Figure 3. Factor of safety for the 160 banks (80 river cross sections) studied. 


\subsubsection{Forest Assessment}

For the forest assessment, field surveys were carried out to identify the existing woody vegetation (both upper and lower levels in terms of the presence of native, indigenous and alien species. The whole length of riparian vegetation was divided into eight sections (Figure 2), and the main vegetation types recorded in each section are presented in Table 1 . Section 1 refers to the estuary section of the river, Sections 2, 3 and 4 to the main river, Section 5 is an artificial irrigation channel, Sections 6 and 7 refer to the Keramianos tributary, and Section 8 to the Anavreti tributary. The vegetation types were matched with the habitat types, which were classified according to the European Nature Information System (EUNIS).

The riparian natural vegetation of the Koiliaris River is basically composed of a few species with a dominant presence of Arundo donax and Platanus orientalis, or many point sites such as Tamarix spp., Vitex agnuscactus, Salix alba, Ricinus communis, Hedera helix (Table 1), which gradually alternate as we move from the estuary to the main river segment. At the lower part of the river (Section 1) the vegetation consists of beds of Phragmites australis and Arundo donax. At Section 2, White Willows (Salix alba) and Oriental Plane trees (Platanus orientalis) appear, at the beginning sporadically, until they gradually dominate, eventually forming a riparian forest. The forest assumes its typical form in Section 3. In this section, the presence of numerous climbing plants (mainly Hedera helix and Vitis vinifera) is characteristic. However, the forest is restricted near the banks of the river. Section 4 is characterized by the presence of Oriental Planes and White Willows which occur either solitary or in lines along the river. Very often the cultivated fields reach the banks, but in other parts of this section there is some space for natural vegetation. Section 5 is of no interest in terms of natural vegetation as it is an artificial irrigation channel. In Section 6, the absence of constant flow inhibits the development of a riparian forest. The upper part of Keramianos tributary comes into contact with zonal vegetation, so many species that are not typical elements of riparian vegetation occur there (e.g., Quercus coccifera and Phillyrea latifolia). At the central part of this section, the vegetation is a riparian scrub of Vitex agnus-castus, Nerium oleander, Tamarix parviflora, Arundo donax and Platanus orientalis which gives place to Provence cane (Arundo donax) beds at its lowest part. In Section 7, the vegetation is transitional between Provence cane beds and riparian forest of White Willows and Oriental Plane trees. In Section 8, which corresponds to the tributary of Anavreti, a riparian vegetation of Oriental Plane is developed (the White Willow is absent in this section). The riparian natural vegetation is not continuous, but it is often interrupted by adjacent cultivated fields. Although the vegetation is not as developed as in the central part of Koiliaris River, at least at some parts could be characterized as a riparian forest.

The main pressure to the forest is the cultivation of fields that are very close to the banks. Taking into consideration that the floodplain is quite large, we can conclude that the natural boundaries of the riparian forest could extend several meters to each side of the river. The partial recovery of fluvial free space could be the solution for both sustainable existence of the forest and reducing to the minimum the effects of bank erosion. What we proposed is a three-zone model similar to that mentioned by Welsch [25] for Sections 2, 3 and 4 of the river, and a two-zone model for the all other sections except Section 5. The three-zone model consists of a zone of undisturbed forest (10 $\mathrm{m}$ in width), a $15 \mathrm{~m}$ width zone of managed forest (where disturbance is allowed) and a $6 \mathrm{~m}$ width zone of cultivated fields that are under special management (e.g., agrochemicals and plowing are not allowed). The two-zone model, is similar but lacks the second zone of the three-zone model as described above. In that case undisturbed vegetation is not always a forest (depending on the site). 
Table 1. Characterization of the riparian vegetation of Koiliaris river.

\begin{tabular}{|c|c|c|c|}
\hline $\begin{array}{c}\text { River } \\
\text { Section }\end{array}$ & Vegetation & $\begin{array}{c}\text { Habitat Types } \\
\text { Recognized }\end{array}$ & Some of the Taxa Recorded \\
\hline 1 & $\begin{array}{c}\text { The natural vegetation } \\
\text { consists of Phragmites australis } \\
\text { and Arundo donax. }\end{array}$ & $\begin{array}{l}\text { Provence cane (Arundo } \\
\text { donax) beds and } \\
\text { Common reed } \\
\text { (Phragmites australis) } \\
\text { beds (EUNIS codes: } \\
\text { C3.32 and C3.21) }\end{array}$ & $\begin{array}{l}\text { Phragmites australis, Arundo donax, } \\
\text { Juncus heldeichianus. Also some } \\
\text { planted species e.g., Tamarix sp., } \\
\text { Washingtonia filifera }\end{array}$ \\
\hline 2 & $\begin{array}{c}\text { Provence cane beds to riparian } \\
\text { forest of Oriental Planes and } \\
\text { White Willows. }\end{array}$ & $\begin{array}{c}\text { Provence cane (Arundo } \\
\text { donax) beds and } \\
\text { Helleno-Balkanic } \\
\text { riparian plane forests } \\
\text { (EUNIS codes: C3.32 and } \\
\text { G1.381) }\end{array}$ & $\begin{array}{l}\text { Arundo donax, Salix alba, } \\
\text { Platanus orientalis, Hedera helix, } \\
\text { Vitis vinifera, Ficus carica }\end{array}$ \\
\hline 3 & $\begin{array}{c}\text { Forest of Oriental Planes } \\
\text { (Platanus orientalis) and White } \\
\text { Willows (Salix alba) with } \\
\text { presence of woody climbing } \\
\text { plants (mainly Hedera helix and } \\
\text { Vitis vinifera). }\end{array}$ & $\begin{array}{l}\text { Helleno-Balkanic } \\
\text { riparian plane forests } \\
\text { (EUNIS code: G1.381) }\end{array}$ & $\begin{array}{l}\text { Salix alba, Platanus orientalis, } \\
\text { Arundo donax, Rubus sanctus, } \\
\text { Morus alba, Ulmus minor, } \\
\text { Ficuss carica, Ricinus communis, } \\
\text { Vitis vinifera, Hedera helix }\end{array}$ \\
\hline 4 & $\begin{array}{c}\text { Riparian vegetation with } \\
\text { Oriental Planes } \\
\text { (Platanus orientalis) and White } \\
\text { Willows (Salix alba). }\end{array}$ & $\begin{array}{l}\text { Helleno-Balkanic } \\
\text { riparian plane forests } \\
\text { (EUNIS code: G1.381) }\end{array}$ & $\begin{array}{c}\text { Platanus orientalis, Hedera helix, } \\
\text { Rubus sanctus, Arundo donax, } \\
\text { Salix alba, Arundo donax, Ficus carica, } \\
\text { Hedera helix, Rubus sanctus, } \\
\text { Juncus heldeichianus }\end{array}$ \\
\hline 5 & $\begin{array}{l}\text { The natural woody vegetation } \\
\text { is very limited. }\end{array}$ & - & $\begin{array}{l}\text { Ficus carica, Morus alba, } \\
\text { Arundo donax, Hedera helix, } \\
\text { Smilax aspera, Rubus sanctus }\end{array}$ \\
\hline 6 & $\begin{array}{l}\text { The natural woody vegetation } \\
\text { consists of shrubs of } \\
\text { NerioTamaricetea } \\
\text { Phytosociological class } \\
\text { (Vitex agnus-castus, } \\
\text { Nerium oleander, } \\
\text { Tamarix parviflora). } \\
\text { Arundo donax beds exist } \\
\text { upstream of riparian scrub. }\end{array}$ & $\begin{array}{c}\text { Oleander, chaste tree } \\
\text { (Vitex agnus-castus) and } \\
\text { tamarisk galleries and } \\
\text { Provence cane } \\
\text { (Arundo donax) beds } \\
\text { (EUNIS codes: F9.31 and } \\
\text { C3.32) }\end{array}$ & $\begin{array}{c}\text { Vitex agnus-castus, Nerium oleander, } \\
\text { Tamarix parviflora, Arundo donax, } \\
\text { Olea europaea, Rubus sanctus, } \\
\text { Quercus coccifera, Phillyrea latifolia, } \\
\text { Ceratonia siliqua, Styrax officinalis, } \\
\text { Cupressus sempervirens, Ficus carica, } \\
\text { Clematis cirrhosa, Hedera helix, } \\
\text { Smilax aspera. Also some allien } \\
\text { species e.g., Yucca sp., } \\
\text { Ricinus communis, } \\
\text { Opuntia ficus-indica, Nicotiana glauca }\end{array}$ \\
\hline 7 & $\begin{array}{l}\text { Provence cane beds that goes } \\
\text { to riparian forest of Oriental } \\
\text { Planes and White Willows. }\end{array}$ & $\begin{array}{c}\text { Provence cane } \\
\text { (Arundo donax) beds and } \\
\text { Helleno-Balkanic } \\
\text { riparian plane forests } \\
\text { (EUNIS codes: C3.32 and } \\
\text { G1.381) }\end{array}$ & $\begin{array}{c}\text { Platanus orientalis, Salix alba, } \\
\text { Arundo donax, Hedera helix, } \\
\text { Vitis vinifera, Ricinus communis, } \\
\text { Rubus sanctus }\end{array}$ \\
\hline 8 & $\begin{array}{l}\text { The natural woody vegetation } \\
\text { consists of Oriental Planes } \\
\text { (Platanus orientalis) }\end{array}$ & $\begin{array}{l}\text { Helleno-Balkanic } \\
\text { riparian plane forests } \\
\text { (EUNIS code: G1.381) }\end{array}$ & $\begin{array}{c}\text { Platanus orientalis, Vitex agnus-castus, } \\
\text { Ficus carica, Rubus sanctus, } \\
\text { Hedera helix, Arundo donax, } \\
\text { Nerium oleander, Clematis cirrhosa, } \\
\text { Vitis vinifera, Smilax aspera, } \\
\text { Ceratonia siliqua }\end{array}$ \\
\hline
\end{tabular}

\subsection{NBS Design Phase}

Our working hypothesis was that the ultimate, most effective solution to river bank erosion is the restoration of the riparian forest. Figure 4 illustrates the effectiveness of native, riparian vegetation in 
protecting from river bank erosion. The left photo is from an eroded area where the orange grove was planted next to the river and the native vegetation was removed. The right photo is a non-eroded area with dense (single line) Oriental planes and other native species. The root density of the orange trees (an alien species that normally does not occur in riparian vegetation) does not create the conditions to consolidate the soil and protect it from erosion.

Recreating the riparian forest with native and indigenous species is the NBS answer to solving the river bank erosion of the Koiliaris River. However, the initial stages of reforestation are not very effective for erosion control. Therefore, additional action needs to be taken for the immediate protection of the eroded and prone to erosion river banks. This immediate action is the protection of the river bank with vegetated stone walls and vegetated rip-rap, as well as revegetated banks depending on the bank slope, erosion potential and existing vegetation.

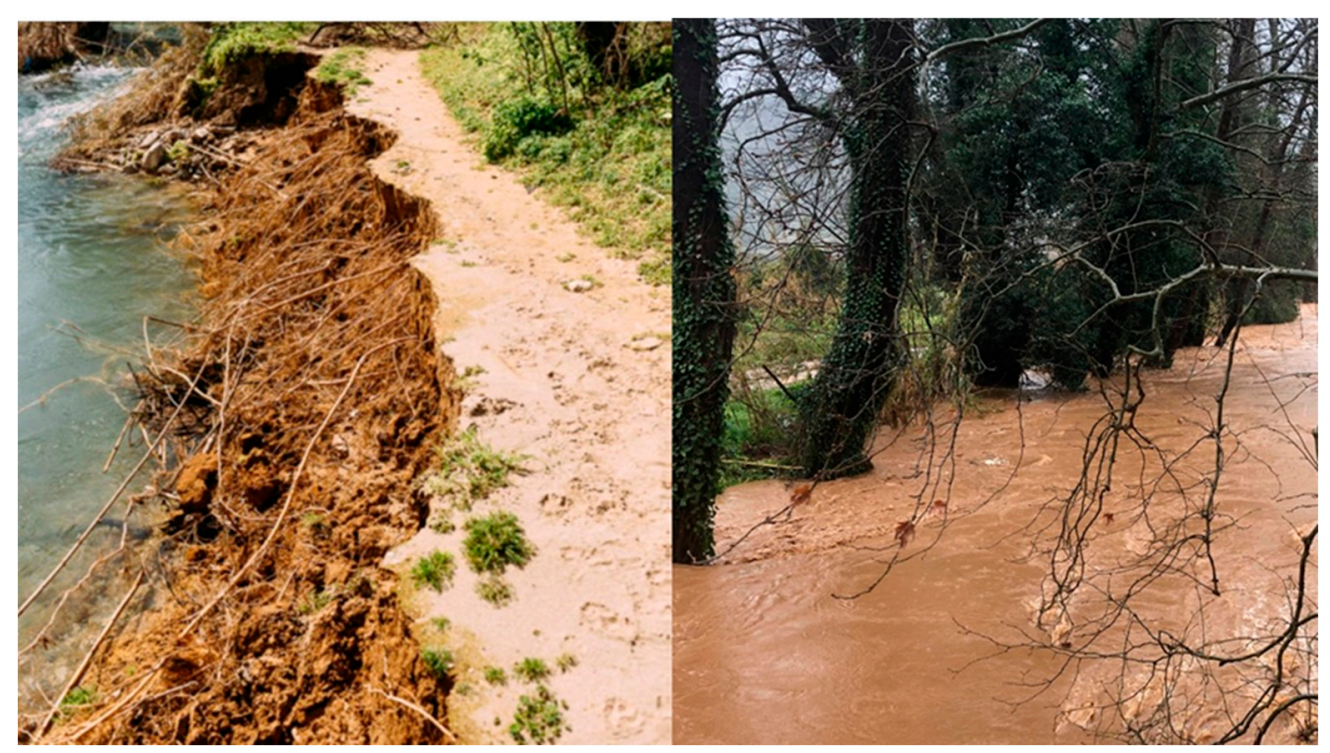

Figure 4. Eroded (left photo) and non-eroded area (right photo) in the Koiliaris River.

The proposed NBS was the restoration of the eroded banks with vegetated walls and rip-raps (Figure 5) together with the restoration of the riparian forest. The latter means that we proposed to restore not only the last tree-row next to the river, but also to reclaim the riparian forest area from agriculture. This is a traditional NBS with multiple benefits for the stability of the banks from erosion as well as for the ecosystem of the river.

The proposal for the restoration of the forest can be divided into two parts. One part for the banks of the river and the other for the rest of the adjacent fields. In the first case, the restoration would take place by implementing soil bioengineering methods. The proposed bioengineering methods were live staking, vegetated riprap stone paving and vegetated stone walls (Figure 5). These could provide both streambank protection and riparian forest restoration. For the rest of the restored riparian areas, the proposed restoration method was by creating a forest in a zone of $25 \mathrm{~m}$ in conjunction with the cultivated fields, by ball-planting Oriental Planes, White Willows and other native trees of the area. 


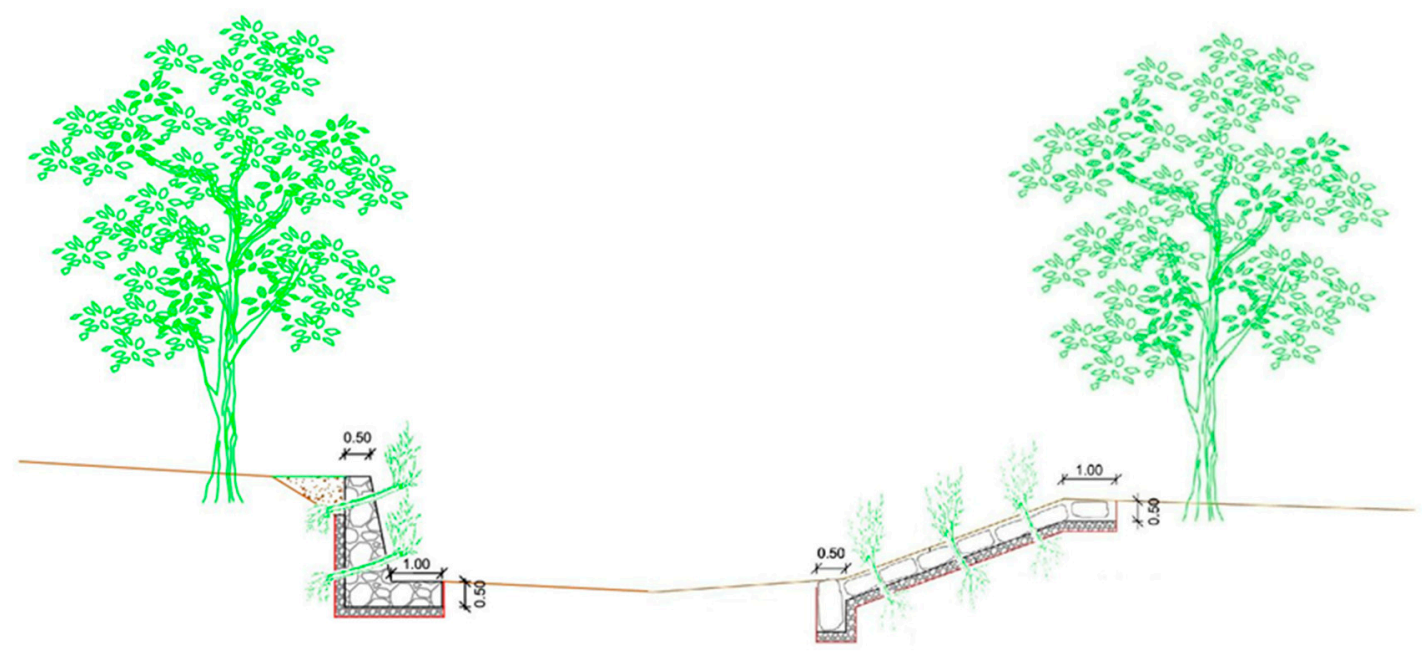

Figure 5. Design of the restoration of the eroded banks with vegetated walls and rip-raps.

Once the basic concept of the design was developed, we moved into the next phase of fine tuning it with the input of the local and regional stakeholders. These participatory activities allowed effective stakeholder involvement for NBS co-design. Stakeholder involvement in the co-design of the final solutions helped overcome the barriers and the conflicting objectives that usually arise in the implementation phase. The stakeholders involved in the processes were representatives in different roles who are related to local and regional governments as well as the local farmers and land owners. The local government was represented from the Mayor of Apokoronas and the Municipality Council that includes all parties and representatives from all villages. The Regional government was represented in the Monitoring Committee of the project, consisting of representatives of the Directorate of the Water Management of the Region, the Regional Unit of Chania, The Municipality of Apokoronas, the Directorate for Technical Services and the Technical University of Crete. The Forestry Directorate of the Region was also invited to the Committee meeting because they are essential players regarding the ultimate approval process in the implementation phase. The Monitoring Committee of the project had regular meetings in order to discuss the NBS design and approve the deliverables of the studies conducted in the Baseline assessment phase. The Directorate for Technical Services had an important role in the process as it was responsible for the prior approval of the design. Finally, the local farmers and land owners, and in general, the general public were the third type of stakeholders that their input was obtained through town hall meetings.

The proposed initial design raised multi-dimensional legislative, socio-economic, technical and personal conflicts that appeared during the consultation process. The most significant socio-economic conflict was the area extent of the flood. A land owner near the river, in order to transfer or sell the property, has to perform a flood delineation and show that the property is outside the flood plain. According the current legislation, flood-susceptible areas cannot be legally transferred, even within the family. The proposed flood plain has a maximum width of $127 \mathrm{~m}$ on both side of the river and many land-owners will be affected.

From the regional perspective, the conflict arose with the riparian forest pedestrian path that runs next to the river. Since the path runs with the floodplain, the Region will be responsible for protecting people by preventing them from walking along the path during a flood event. Given that this is a major responsibility which can be prone to mishaps, the Regional representatives, and especially the Technical Services, were suggesting a redesign that would include flood control and an alternative design of the path. Reduction in the flood plain width was also suggested by the Municipal authorities as a way to gain the acceptability of the local stakeholders.

The golden solution to overcome these conflicts was to reduce the flood plain to $20 \mathrm{~m}$ on either side of the river by creating a forested levee that would run from the Stylos springs to the Koiliaris 
River estuary, a distance close to $5 \mathrm{Km}$. Therefore, the $20 \mathrm{~m}$ of riparian forest will comprise a 10-m section and then $10 \mathrm{~m}$ for the forested levee. The levee will be about $2 \mathrm{~m}$ in height. There will be a $3-\mathrm{m}$ walking path at the top of the levee and trees will be planted on the slopes following the original design. In this way, we can achieve river bank erosion protection, with the creation of $20 \mathrm{~m}$ on each side for $5 \mathrm{~km}$ riparian forest as well as flood control (Figure 6). The land owners will give up $20 \mathrm{~m}$ of their property; however, the remaining property will increase in value significantly since it could be transferred or sold. Figure 7 presents the flood zone after the restoration of the riparian forest and the flood protection measures.

The final design was presented to the Municipality Council and the Mayor and had the full support of all the parties. Finally, two open local stakeholder meetings were carried out during the NBS design phase, where all stakeholders participated in order to discuss the final solution and present all the dimensions and issues of the proposed solutions.

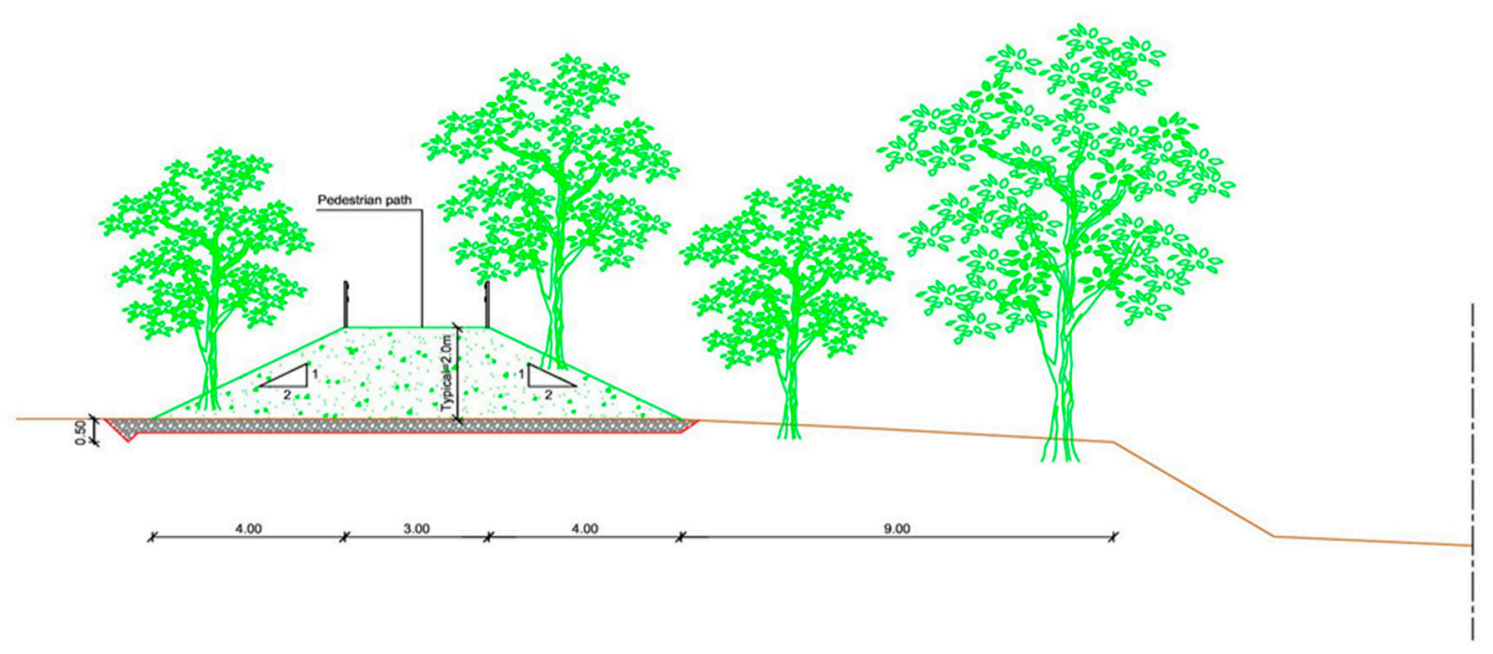

Figure 6. Flood protection design.

\subsection{Implementation Phase}

The final phase of the decision-making methodology is the implementation step, which includes obtaining approvals from various Departments of the Decentralized Administration of Crete, securing funding, and the continuous assessment and evaluation of the NBS proposed in the design phase.

Regarding governmental approvals, the Environmental Impact Assessment with the proposed design has been submitted to the Department of Environment and Spatial Planning of the Decentralized Administration of Crete to approve and to establish the environmental requirements for the project. The Department will request opinions from the following Departments: Water Division and Forestry of the Decentralized Administration, Ephorate of Antiquities of Chania (Ministry of Culture and Sports), Municipality of Apokoronas Council, and the Environmental and Water Resources Unit of the Regional Unit of Chania. The Department of Environment and Spatial Planning will forward the request and the recommendation to the Regional Council for final approval. Upon approval, the procurement details with the estimated cost will be prepared for the tender. 


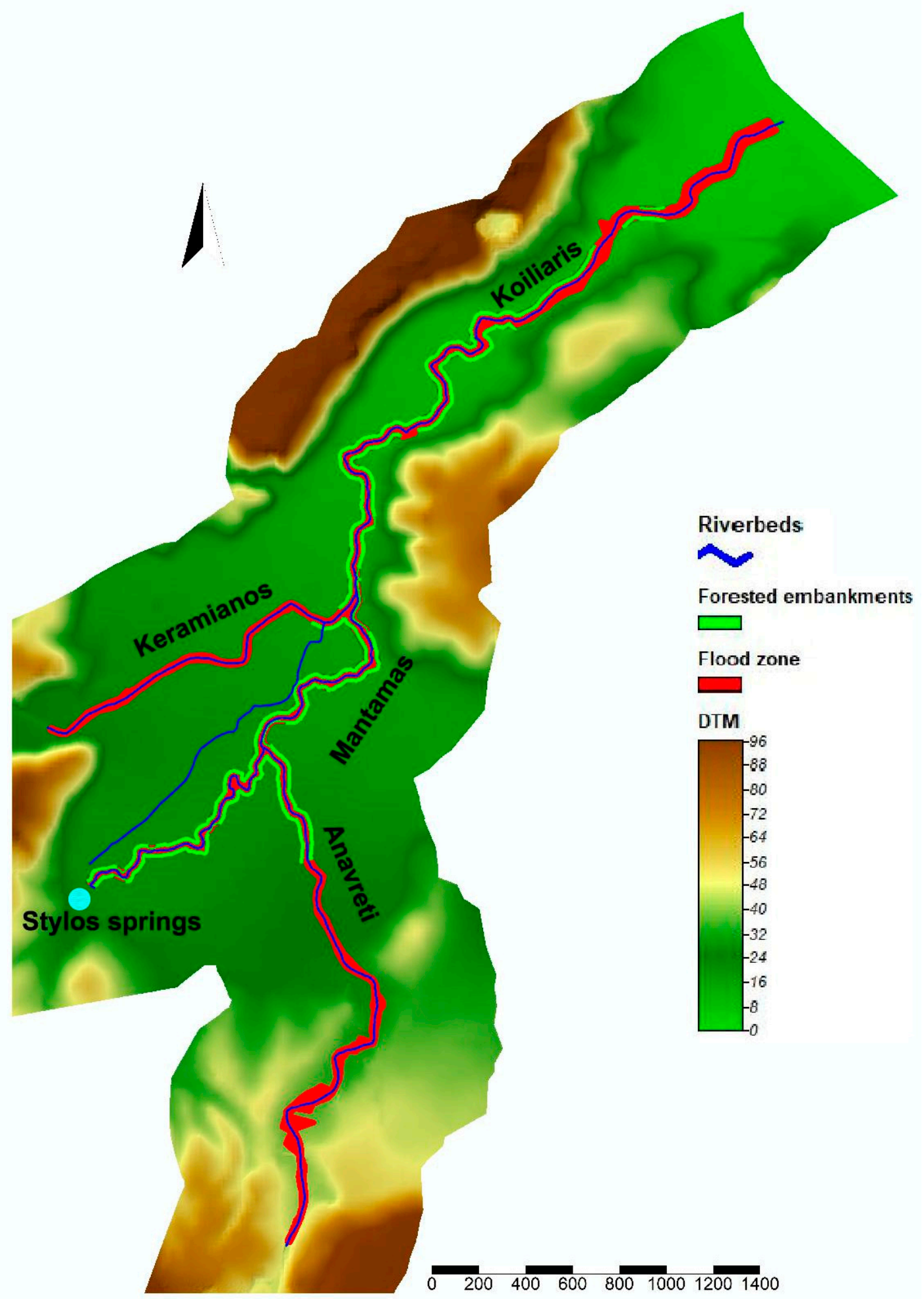

Figure 7. The flood zone after the restoration of the riparian forest and the flood protection measures.

The second phase of implementation is to secure the funding for the project which is estimated to be around EUR 3 to 3.5 million. The alternative funding mechanisms are the following: a) the project to be included in the funding of the structural funds, or b) to obtain national funding that have been allocated to various Ministries or the Region of Crete. In addition, funding from last year's emergency disaster funds can be used to complete the project. The Municipality of Apokoronas will work together with Region of Crete to resolve the issue. 
Finally, the third phase involves the continuous assessment and evaluation of the NBS by using Key Performance Indicators (KPIs). In order to determine the KPIs that are necessary for the continuous assessment, maintenance and evaluation of the NBS, we need to classify the proposed NBS and determine the NBS approach used, the NBS challenges addressed and the ecosystem services provided. The NBS used in Koiliaris CZO was classified according to the NBS classification scheme which was a result of a synthesis conducted from a literature review and stakeholder consultation and discussion on the ThinkNature platform (https://platform.think-nature.eu), following four distinct approaches that together identify the uniqueness and usefulness of the NBS [12]. The NBS used in Koiliaris $\mathrm{CZO}$, according to the degree of intervention and the level of engineering, was classified to the 3rd Type-design and management of new ecosystems, and specifically in the category of the ecological restoration of degraded terrestrial ecosystems. The NBS were further classified into the following NBS types:

- Systems for erosion control

- Soil and slope revegetation

- Plant trees/ hedges/perennial grass strips to intercept surface run-off

- Use of pre-existing vegetation

In addition, Table 2 presents a list of NBS approaches, challenges to be solved and ecosystem services provided related to the NBS proposed for the bank and riparian forest restoration of Koiliaris River. Based on this classification and characterization of the NBS following the ThinkNature project classification, we propose eight indicators for the future monitoring of the NBS performance, that are related to five NBS challenges and are presented in Table 3.

The project is expected to increase the carbon storage in the area by about $1-2 \%$, reduce the flood up to a maximum hourly flow of $127 \mathrm{~m}^{3} / \mathrm{s}$, increase public health and well-being, as well as provide economic potential and green jobs. The present-day participation of stakeholder involvement is considered exceptional and is expected to be maintained in the future (Table 3).

The proposed NBS solution offers the following co-benefits:

- Protection of the river in a sustainable way.

- Improvement of the biodiversity of the river and the riparian area.

- Improving the water quality of the river.

- Creation of a park of high ecological value.

- Improving the quality of life of the local people and social cohesion.

- Opportunity for tourism and agriculture cooperation and the creation of new jobs.

- Creation of a riparian forest which will be a reference point for the development of unique and high-quality agricultural products and can be used as a marketing tool for their promotion.

- It is an exemplary example of a functional ecosystem restoration that can be used for flood and erosion protection in many parts of the world.

The project highlights the determination of the local community and the Municipality of Apokoronas to show that they:

- Believe in the sustainable development of the area.

- $\quad$ Respect and protect nature.

- Demonstrate commitment to sustainable land management and the production of quality products. 
Table 2. List of NBS approaches, challenges to be solved and ecosystem services related to Koiliaris CZO.

\begin{tabular}{|c|c|}
\hline NBS Approach & NBS Challenge to be Solved/SDGs \\
\hline 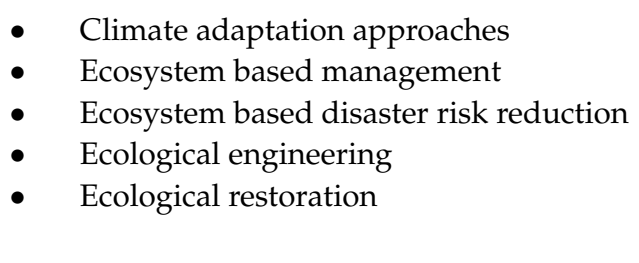 & $\begin{array}{l}\text { - } \quad \text { Climate mitigation and adaptation } \\
\text { - } \quad \text { Participatory planning and governance } \\
\text { - } \quad \text { Public health and well-being } \\
\text { - } \quad \text { Potential of economic opportunities and } \\
\text { green jobs }\end{array}$ \\
\hline \multicolumn{2}{|c|}{ Ecosystem services provided } \\
\hline Provisioning services & Regulation and Maintenance \\
\hline $\begin{array}{ll}\text { - } & \text { Raw (biotic) materials } \\
\text { - } & \text { Water for non-drinking purposes }\end{array}$ & \multirow{3}{*}{$\begin{array}{ll}\text { - } & \text { Carbon sequestration } \\
\text { - } & \text { Local climate regulation } \\
\text { - } & \text { Water purification } \\
\text { - } & \text { Erosion prevention } \\
\text { - } & \text { Flood protection } \\
\text { - } & \text { Maintaining populations and habitats } \\
\text { - } & \text { Soil formation and composition }\end{array}$} \\
\hline Cultural & \\
\hline $\begin{array}{ll}\text { - } & \text { Recreation } \\
\text { - } & \text { Aesthetic appreciation } \\
\text { - } & \text { Spiritual and symbolic appreciation }\end{array}$ & \\
\hline
\end{tabular}

Table 3. Key performance indicators per NBS challenge to be solved related to the case study of Koiliaris CZO.

\begin{tabular}{|c|c|c|c|}
\hline NBS Challenge & Indicators & Current Impact & Expected Impact \\
\hline $\begin{array}{c}\text { Climate mitigation and } \\
\text { adaptation }\end{array}$ & $\begin{array}{l}\text { Carbon storage and } \\
\text { sequestration in } \\
\text { vegetation and soil }\end{array}$ & $\begin{array}{l}\text { Low density agricultural } \\
\text { vegetation, limited } \\
\text { riparian forest and 1-2\% } \\
\text { OC typical soil carbon }\end{array}$ & $\begin{array}{l}40 \text { m length high density } \\
\text { riparian forest with soil } \\
\text { carbon to increase to } \\
3-4 \% \text { at maturity. }\end{array}$ \\
\hline \multirow[t]{2}{*}{ Water management } & Reduction of flood risk & None & $\begin{array}{c}\text { 50-year flood or } \\
\text { maximum hourly flow of } \\
127 \mathrm{~m}^{3} / \mathrm{s}\end{array}$ \\
\hline & $\begin{array}{c}\text { Areas (ha) exposed to } \\
\text { flooding }\end{array}$ & 56 & 31 \\
\hline \multirow[t]{3}{*}{$\begin{array}{l}\text { Participatory planning } \\
\text { and governance }\end{array}$} & $\begin{array}{l}\text { Number of meetings } \\
\text { held with citizens to } \\
\text { explain the progress of } \\
\text { the project }\end{array}$ & $\begin{array}{l}\text { Two meetings during the } \\
\text { design phase and one } \\
\text { with the municipality }\end{array}$ & To be determined \\
\hline & $\begin{array}{l}\text { Numbers of persons } \\
\text { involved in the activities } \\
\text { carried out under the } \\
\text { project }\end{array}$ & 50 people per meeting & To be determined \\
\hline & $\begin{array}{l}\text { Number of public } \\
\text { officials in the relevant } \\
\text { area, who have been } \\
\text { involved in the execution } \\
\text { of activities in the } \\
\text { execution of the project }\end{array}$ & $\begin{array}{l}\text { Mayor, Municipality } \\
\text { Council, Deputy } \\
\text { Governor of Chania, } \\
\text { Regional officials }\end{array}$ & $\begin{array}{l}\text { Mayor, Municipality } \\
\text { Council, Deputy } \\
\text { Governor of Chania, } \\
\text { Regional officials }\end{array}$ \\
\hline $\begin{array}{l}\text { Public health and } \\
\text { well-being }\end{array}$ & $\begin{array}{l}\text { Increase in walking and } \\
\text { cycling in and around } \\
\text { areas of interventions }\end{array}$ & Minimum & High \\
\hline $\begin{array}{l}\text { Potential of economic } \\
\text { opportunities and green } \\
\text { jobs }\end{array}$ & New businesses attracted & Minimum & High \\
\hline
\end{tabular}




\section{Conclusions}

The Koiliaris River watershed is a CZO on the island of Crete and part of the European LTER (Long Term Ecological Research) Network and the LTER-Greece Network, and has been extensively studied over the past 15 years. Research output from the Koiliaris CZO has been used to put together the scientific puzzle on how the Mediterranean geo-environment functions and develop the tools for sustainable water and land management. In addition, the active stakeholder involvement in the research and applied activities for water management and agricultural activities taking place in Koiliaris CZO has established the Technical University of Crete and our research team as an "institution", accepted by the local people and that has been the "catalyst" for social consensus in solving local societal problems.

Within the context of this project, the study and implementation of the flood protection problem with the use of NBS in the Koiliaris River is an extremely lengthy process, and possesses significant barriers to developing optimal solutions. This case faced legislative, financial, technical and social barriers that we had to effectively overcome. As far as the legislative barriers, there is a lengthy approval process for the study that involves multiple institutions with conflicting objectives. In addition, the approval process becomes lengthier when non-mainstream solutions such as NBS are involved. The identification of funding mechanisms for both financing the study as well as the restoration work is a major barrier especially under conditions of economic austerity. Typically, the study has to be financed by the Region using National funding. On the other hand, the implementation can be funded through Structural funds or through the Program of Public Investment. Technical barriers to implementing NBS can manifest both from the perspective of the remediation company (i.e., lack of knowledge to design the restoration of riparian forest) as well as from the governmental agency that issues the permits (i.e., lack of knowledge to approve the design resulting in potential delays in permitting). A significant social barrier was the acceptance of local stakeholders and farmers to reclaim agricultural area and restore the riparian forest. We have been able to effectively overcome these barriers because of our relation with the local stakeholders over the past 15 years and our ability to fuse the vision of the riparian forest restoration to all levels of stakeholders. This vision "drove" the project and created the necessary consensus that is necessary to achieve its objectives which convert privately owned, prime agricultural land to riparian forest.

The development of a global vision for agricultural development of the area and its linking with the river and riparian forest restoration, and also the creation of a decision-making approach to designing and implementing NBS that would act as a driver to overcome the barriers and enhance the social acceptability of the project was, therefore, an urgent need for other NBS projects.

The proposed NBS solution offers an exemplar of a functional ecosystem restoration project that can be used for flood and erosion protection in many parts of the world. It is a solution that protects the river in a sustainable way, improves its biodiversity and water quality as well as the quality of life of the local people and social cohesion. The area can be used as a reference point for the development of unique and high-quality agricultural products and be the "catalyst" for sustainable agricultural development.

Author Contributions: The authors contributed as follows to the manuscript: conceptualization, M.A.L. and N.P.N.; data curation, M.A.L., S.D.N., C.R., M.K., D.E., D.K., M.A., A.T. and K.P.; software, C.R., S.D.N. and M.A.L.; funding acquisition, N.P.N.; methodology, M.A.L. and N.P.N.; project administration, N.P.N.; Resources, M.A.L.; supervision, N.P.N.; visualization, C.R.; writing - original draft preparation, M.A.L. and N.P.N.; writing - review \& editing, S.D.N. and P.L. All authors have read and agreed to the published version of the manuscript.

Funding: This work was funded by the "Research project for the integrated intervention of protection of the riparian forest and the flood protection of Koiliaris River", Contract of the article 100 of the Law 3852/2010 between the Region of Crete, the Municipality of Apokoronas and the Technical University of Crete. The authors also acknowledge funding from the H2020 CSA project THINKNATURE (Grant number 730338) and the H2020 INFRAIA eLTER PLUS (Grant number 871128).

Acknowledgments: The authors would like also to thank the personnel from the Region of Crete and the Municipality of Apokoronas for their active participation in the co-design of the Nature-based solution. 
Conflicts of Interest: The authors declare no conflict of interest.

\section{References}

1. Cohen-Shacham, E.; Walters, G.; Janzen, C.; Maginnis, S. (Eds.) Naturebased Solutions to Address Global Societal Challenges; IUCN: Gland, Switzerland, 2016.

2. Maes, J.; Jacobs, S. Nature-based solutions for Europe's sustainable development. Conserv. Lett. 2015, 10, 121-124. [CrossRef]

3. EC. Nature-Based Solutions \& Re-Naturing Cities. Final Report of the Horizon 2020 Expert Group on 'Nature-Based Solutions and ReNaturing Cities'. Directorate-General for Research and Innovation-Climate Action, Environment, Resource Efficiency and Raw Materials. 74. 2015. Available online: http://dx.doi.org/ 10.2777/765301 (accessed on 23 March 2015).

4. Cohen-Shacham, E.; Andrade, A.; Dalton, J.; Dudley, N.; Jones, M.; Kumar, C.; Maginnis, S.; Maynard, S.; Nelson, C.R.; Renaud, F.G.; et al. Core principles for successfully implementing and upscaling Naturebased Solutions. Environ. Sci. Policy 2019, 98, 20-29. [CrossRef]

5. Faivre, N.; Fritz, M.; Freitas, T.; de Boissezon, B.; Vandewoestijne, S. Nature-based solutions in the EU: Innovating with nature to address social, economic and environmental challenges. Environ. Res. 2017, 159, 509-518. [CrossRef]

6. Faivre, N.; Sgobbi, A.; Happaerts, S.; Raynal, J.; Schmidt, L. Translating the Sendai Framework into action: The EU approach to ecosystem-based disaster risk reduction. Int. J. Disaster Risk Reduct. 2018, 32, 4-10. [CrossRef]

7. Keesstra, S.; Nunes, J.; Novara, A.; Finger, D.; Avelar, D.; Kalantari, Z.; Cerdà, A. The superior effect of nature based solutions in land management for enhancing ecosystem services. Sci. Total. Environ. 2018, 610-611, 997-1009. [CrossRef]

8. Kabisch, N.; Frantzeskaki, N.; Pauleit, S.; Naumann, S.; Davis, M.; Artmann, M.; Haase, D.; Knapp, S.; Korn, H.; Stadler, J.; et al. Nature-based solutions to climate change mitigation and adaptation in urban areas: Perspectives on indicators, knowledge gaps, barriers, and opportunities for action. Ecol. Soc. 2016, 21, 39. [CrossRef]

9. Albert, C.; Schroter, B.; Haasec, D.; Brillinger, M.; Henze, J.; Herrmann, S.; Gottwald, S.; Guerrero, P.; Nicolas, C.; Matzdorf, B. Addressing societal challenges through nature-based solutions: How can landscape planning and governance research contribute? Landsc. Urban Plan. 2019, 182, 12-21. [CrossRef]

10. Perrone, A.; Inam, A.; Albano, R.; Adamowski, J.; Sole, A. A participatory system dynamics modeling approach to facilitate collaborative flood risk management: A case study in the Bradano River (Italy). J. Hydrol. 2020, 580, 124354. [CrossRef]

11. Naumann, S.; Anzaldua, G.; Berry, P.; Burch, S.; Davis, M.; Frelih-Larsen, A.; Gerdes, H.; Sanders, M. Assessment of the Potential of Ecosystem-Based Approaches to Climate Change Adaptation and Mitigation in Europe. Final Report to the European Commission, DG Environment; Contract no. 070307/2010/580412/SER/B2; Ecologic Institute and Environmental Change Institute, Oxford University Centre for the Environment: Oxford, UK, 2011.

12. Somarakis, G.; Stagakis, S.; Chrysoulakis, N. (Eds.) ThinkNature Nature-Based Solutions Handbook. In ThinkNature Project Funded by the EU Horizon 2020 Research and Innovation Programme under Grant Agreement; European Commission: Brussels, Belgium, 2019; No. 730338. [CrossRef]

13. Rizvi, A.R.; Baig, S.; Verdone, M. Ecosystems Based Adaptation: Knowledge Gaps in Making an Economic Case for Investing in Nature Based Solutions for Climate Change; IUCN: Gland, Switzerland, 2015.

14. Wamsler, C.; Wickenberg, B.; Hanson, H.; Alkan Olsson, J.; Stålhammar, S.; Björn, H.; Falck, H.; Gerell, D.; Oskarsson, T.; Simonsson, E.; et al. Environmental and climate policy integration: Targeted strategies for overcoming barriers to nature-based solutions and climate change adaptation. J. Clean. Prod. 2019, 247, 119154. [CrossRef]

15. Kabisch, N.; Korn, H.; Stadler, J.; Bonn, A. (Eds.) Nature-based Solutions to Climate Change Adaptation in Urban Areas: Linkage between Science, Policy and Practice; Springer: Cham, Switzerland, 2017. [CrossRef]

16. Tyler, S.; Moench, M. A framework for urban climate resilience. PLoS ONE 2012, 12, 311-326. [CrossRef]

17. Timpane-Padgham, B.L.; Beechie, T.; Klinger, T. A systematic review of ecological attributes that confer resilience to climate change in environmental restoration. PLoS ONE 2017, 12, 1-23. [CrossRef] [PubMed] 
18. Raymond, C.M.; Frantzeskaki, N.M.; Kabisch, N.; Berry, P.; Breil, M.; Nita, M.R.; Geneletti, D.; Calfapietra, C. A framework for assessing and implementing the co-benefits of nature-based solutions in urban areas. Environ. Sci. Policy 2017, 77, 15-24. [CrossRef]

19. Yu, X.; Moraetis, D.; Nikolaidis, N.P.; Li, B.; Duffy, C.; Liu, B. A coupled surface-subsurface hydrologic model to assess groundwater flood risk spatially and temporally. Environ. Model. Softw. 2019, 114, 129-139. [CrossRef]

20. Mitchell, R.K.; Agle, B.R.; Wood, D.J. Toward a theory of stakeholder identification and salience: Defining the principle of who and what really counts. Acad. Manag. Rev. 1997, 22, 853-886. [CrossRef]

21. Nerantzaki, S.D.; Hristopulos, D.T.; Nikolaidis, N.P. Estimation of the uncertainty of hydrologic predictions in a karstic Mediterranean watershed. Sci. Total Environ. 2020, 717, 137131. [CrossRef] [PubMed]

22. Kourgialas, N.N.; Karatzas, G.P.; Nikolaidis, N.P. An integrated framework for the hydrologic simulation of a complex geomorphological river basin. J. Hydrol. 2010, 381, 308-321. [CrossRef]

23. Nikolaidis, N.P.; Bouraoui, F.; Bidoglio, G. Hydrologic and geochemical modeling of a karstic Mediterranean watershed. J. Hydrol. 2013, 477, 129-138. [CrossRef]

24. Hydrologic Engineering Center. Hydraulic Reference Manual, US Army Corps of Engineers, Davis; Hydrologic Engineering Center: California, CA, USA, 2001.

25. Welsch, D. Riparian Forest Buffers. US Department of Agriculture, Forest Service. Forest Resources Management; No. NA-PR-07-91; FS Pub: Radnor, PA, USA, 1991.

(C) 2020 by the authors. Licensee MDPI, Basel, Switzerland. This article is an open access article distributed under the terms and conditions of the Creative Commons Attribution (CC BY) license (http://creativecommons.org/licenses/by/4.0/). 